\title{
Disk Device
}

National Cancer Institute

\section{Source}

National Cancer Institute. Disk Device. NCI Thesaurus. Code C49925.

Any device component shaped like a disk, especially those used for data storage. 